ISSN 1392-3196 / e-ISSN 2335-8947

Zemdirbyste-Agriculture, vol. 101, No. 2 (2014), p. 115-124

DOI 10.13080/z-a.2014.101.015

\title{
Influence of different farming systems on the stability of low productivity soil in Southeast Lithuania
}

\author{
Eugenija BAKŠIENE ${ }^{1}$, Almantas RAŽUKAS ${ }^{1}$, Jūratė REPEČKIENE ${ }^{2}$, Jelena TITOVA \\ ${ }^{1}$ Vokè Branch, Lithuanian Research Centre for Agriculture and Forestry \\ Žalioji 2, Trakų Vokè, Vilnius \\ E-mail: eugenija.baksiene@voke.lzi.lt \\ ${ }^{2}$ Institute of Botany, Nature Research Centre \\ Žaliųų Ežerų 49, Vilnius
}

\begin{abstract}
Complex investigations designed to explore the impact of extensive, organic-sustainable and conventional-chemical farming systems on changes of soil chemical, physical and microbiological properties of sandy loam Haplic Luvisol (LVh) were performed at the Vokė Branch of the Lithuanian Research Centre for Agriculture and Forestry during 2003-2012. The studies were carried out employing different crop rotations, where the plant sequence was laid out in four treatments so that the plant residues in the soil would accumulate more organic matter and nitrogen. Research evidence showed that different farming systems and plant sequences in rotations did not affect soil acidity, but significantly increased the contents of total nitrogen and organic carbon and reduced the contents of available phosphorus and potassium. Soil physical properties changed accordingly. Higher moisture levels were determined in soil under extensive and conventional-chemical farming systems. At the lower soil layers the impact of green manure on the reduction of soil bulk density and increase of total and air-filled porosity was evident. Extensive and conventional-chemical farming systems favoured the distribution of fungi in the soil. With the application of organic farming system, the balance between the number of ammonifying and mineral nitrogen assimilating bacteria was maintained.
\end{abstract}

Key words: bacteria, chemical-physical properties, farming systems, fungi, soil.

\section{Introduction}

Organic farming emerged in the 1920 s with the concept of an inextricable link between soil, plant and animal health and of the composting process as an important element to obtain this (Jakobsen, 2012). After lengthy discussions, the International Federation of Organic Agriculture Movements (IFOAM) concluded that organic agriculture is a production system that sustains the health of soils, ecosystems and people as well as relies on ecological processes, biodiversity and cycles adapted to local conditions. Organic agriculture combines tradition, innovation and science to benefit the shared environment and promote fair relationships and a good quality of life for all involved. The organic production, therefore, requires considerable knowledge for organization of training, development and scientific research (IFOAM, 2008).

Organic and sustainable agriculture is especially important for industrialized countries, where high rates of fertilizers and pesticides are often applied to maximize crop productivity. However, there are fewer opportunities for organic and sustainable agriculture on less productive (acid, eroded or sandy) soils and these systems could lower quality standards. Therefore, conservation agriculture could be complimentary and integrated with organic and sustainable agriculture. For the development of integrated arable farming systems, tools are needed to evaluate the achievement of agronomic and environmental objectives, in order to optimize the systems (Jaskulski, Jaskulska, 2012).
Most organic farms of Lithuania are located in areas with predominating light textured soils. It is particularly important to maintain the fertility of such soils with priority for renewable resources. In organic farming systems, soil fertility means more than just provision of plants with macro- and microelements. Plant fertility results from accumulation of soil organic matter and soil biology. In organic farming systems it is therefore important to improve soil fertility and at the same time to protect and improve soil physical condition for its healthy functioning. Maintenance and improvement of soil potential fertility are closely related to the maintenance of soil organic matter and organic carbon balance, so a variety of soil improvement measures - fertilization with farmyard manure, green manure, selection of the most appropriate crop rotation, cultivation of plant species that are most suitable in the sandy loam soil - should be employed (Tripolskaja, 2005; Wander, 2009). Often the remaining plant roots and residues are not sufficient; the deficiency of high-quality organic fertilizers becomes evident, so with progressing de-humification processes humus-protecting farming systems and crop rotation with green manure crops should be applied. Crop rotations enhance the productivity of all crops in the rotation and benefit the soil, as well. Some of the advantages of a wellmanaged crop rotation are improved yields, breaking plant pest cycles, maintaining soil fertility and reducing fertilizer inputs, and controlling erosion. Cover crops and green manures are also part of the crop rotation in many 
sustainable land management systems (Rachman et al., 2003; Florentin et al., 2010). When crops are cultivated successively or grown in longer chains, humus loss takes place, because as a result of a lack of easily degradable organic matter heterotrophic microflora starts consuming humus as an energy source.

Microorganisms functioning in the rhizosphere and rhizoplane are particularly important for plant nutrition as they provide plants not only with available nitrogen, phosphorus, and potassium compounds but also with physiologically active substances that stimulate plant growth. Microorganism diversity ensures destruction of crop residues and maintains soil ecosystem balance (Wang et al., 2010). Quantitative and qualitative composition of the soil microorganism communities varies influenced by multiple biotic and abiotic factors. One of the most important abiotic factors for the abundance of microorganism groups is the soil moisture (Kibblewhite et al., 2008). Eco-friendly approach to effective farming brings in the problem of plant residues destruction and re-introduction into the metabolic cycle. Microorganisms are the most important degraders of organic material in biogeocenosis. Due to metabolites excreted by the roots and chemical composition of plant residues, the plants grown in crop rotation alter the abundance and species composition of microorganism populations.
The research was aimed to explore the impact of extensive, organic-sustainable and intensive-chemical farming systems and different crop rotations on the changes of chemical and physical properties of soil, abundance and variations of microorganism (fungi, bacteria) groups in a sandy loam Haplic Luvisol ( $L V h)$.

\section{Materials and methods}

Field trials. Field experiments were conducted at the Voke Branch of the Lithuanian Research Centre for Agriculture and Forestry during 2003-2012 in a sandy loam Haplic Luvisol (LVh) with a $\mathrm{pH}_{\mathrm{KCl}}$ of 5.9, phosphorus (P) - 70-92 mg kg-1, potassium (K) - 142-165 mg kg-1, organic carbon $(\mathrm{C})-0.79-0.84 \%$. Tests were carried out in different crop rotations, where four treatments of the 5-course (years) plant sequence was applied aiming to ensure maximum organic matter and nitrogen accumulation in the soil and its rational use for crop yield (Table 1). Three treatments of agronomic practices were used in plant cultivation: 1) no addition of $\mathrm{N}, \mathrm{K}$ or $\mathrm{K}$ fertilizers (extensive farming system); 2) no addition of nitrogen, plants fertilized with bone meal $\left(20 \% \mathrm{P}_{2} \mathrm{O}_{5}\right)$ and potash magnesia $\left(26-28 \% \mathrm{~K}_{2} \mathrm{O}\right)$ (organic-sustainable farming system); 3) plants fertilized with mineral $\mathrm{N}, \mathrm{P}$ and $\mathrm{K}$ fertilizers, chemical plant protection measures applied (conventional-chemical farming system).

Table 1. The treatments of experiments - various crop rotations

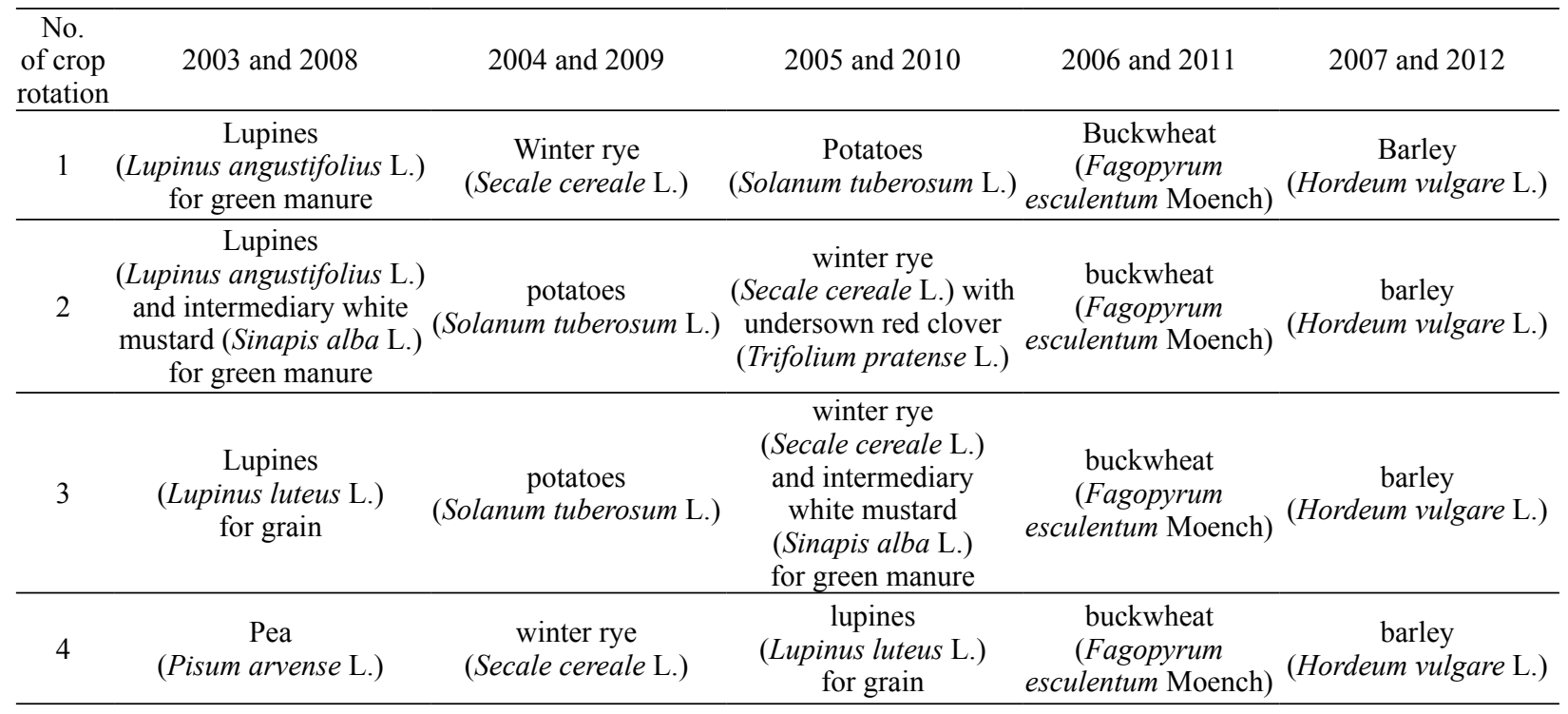

Soil tests. Soil samples for agrochemical analysis were taken from the arable layer $(0-25 \mathrm{~cm})$ before the trial in 2003, after the first 5-year rotation in 2007, and after the second crop rotation in 2012. The determined parameters: $\mathrm{pH}$ - by potentiometric method (ISO 10390, 1994), exchangeable bases $-0.1 \mathrm{M} \mathrm{BaCl}_{2}(1: 10)$ extract method (ISO 11260, 1994), mobile phosphorus $\left(\mathrm{P}_{2} \mathrm{O}_{5}\right)$ and potassium $\left(\mathrm{K}_{2} \mathrm{O}\right)$ - by Egner-Riem-Domingo $\left(\mathrm{A}^{2}-\mathrm{L}_{5}\right)$ method (GOST 26208-91, 1993), total nitrogen (N) - by Kjeldahl method (ISO 11261, 1995), organic C content - spectrophotometrically after sulfochromic oxidation (dry combustion method, ISO 14235, 1998). Every year having sown plants in spring $(\mathrm{Sp})$ and after harvesting in autumn $(\mathrm{Au})$ soil bulk density, moisture, and total porosity of the soil were determined. Soil bulk density, moisture, and total porosity were estimated by the weighing.

Microbiological analysis. The soil samples for the microbiological analysis were taken twice a year: at the beginning of vegetation and after harvesting, from $0-20 \mathrm{~cm}$ layer. Cultivable microorganisms were isolated applying the dilution method by sowing soil suspension in three replications on the surface of standard media for different microorganism groups. Malt agar with chloramphenicol (50 $\mathrm{mg} \mathrm{L}^{-1}$, for bacterium growth inhibition) was used for total fungi; nutrient agar ("Liofilmchem", Italy) - for ammonifying bacteria, starch-ammonia agar: $\left(\mathrm{NH}_{4}\right)_{2} \mathrm{SO}_{4}$ $-2, \mathrm{~K}_{2} \mathrm{HPO}_{4}-1, \mathrm{MgSO}_{4}-1, \mathrm{NaCl}-1, \mathrm{CaCO}_{3}-3$, starch -10 , agar $-20 \mathrm{~g} \mathrm{l}^{-1}$ for mineral $\mathrm{N}$ assimilating bacteria count. The number of bacteria and fungi was expressed as a colony forming units per gram of dry soil (CFU g ${ }^{-1}$ d.s.) (Soil sampling..., 1993; LST ISO 10381-6, 1998).

Statistical analysis. The data was processed using computer software ANOVA and EXCEL 2000, version 2.2 (Tarakanovas, Raudonius, 2003). 


\section{Results and discussion}

Tillage, crop rotations inevitably affect the changes of soil chemical and physical properties. Using different farming systems in light textured soils, it is important to maintain soil fertility potential. For this purpose the crop rotations that can enrich the soil with organic matter and have positive effects on various soil properties are chosen. Soil acidity is a parameter affecting the solubility and suitability of nutrients in soil. Factors affecting soil $\mathrm{pH}$ include organic matter decomposition, transformation into compounds available for plant nutrition. Nutrient intake changes depending on the soil pH (McCauley et al., 2009). In extensive and organic-sustainable farming systems soil acidity $(\mathrm{pH}$ and exchangeable bases) ratios varied within the error range, but in all cases the trend towards acidification reduction was observed: $\mathrm{pH}$ ranged from 5.8 to 6.0 , and the exchangeable bases decreased from $7.7-8.8$ to 6.2-7.6 mequiv $\mathrm{kg}^{-1}$ (Table 2).

Table 2. The effect of farming system on the agrochemical indices in various crop rotations

\begin{tabular}{|c|c|c|c|c|c|c|}
\hline \multirow[t]{2}{*}{ Treatment } & \multirow[t]{2}{*}{$\mathrm{pH}_{\mathrm{KCl}}$} & \multirow[t]{2}{*}{$\begin{array}{c}\text { Exchangeable bases } \\
\text { mequiv kg-1 }\end{array}$} & $\begin{array}{c}\text { Total } \\
\text { nitrogen } \\
(\mathrm{N})\end{array}$ & $\begin{array}{l}\text { Organic } \\
\text { Carbon } \\
(\mathrm{C})\end{array}$ & $\begin{array}{l}\text { Phosphorus } \\
\text { (P) }\end{array}$ & $\begin{array}{l}\text { Potassium } \\
(\mathrm{K})\end{array}$ \\
\hline & & & \multicolumn{2}{|c|}{$\%$} & \multicolumn{2}{|c|}{$\mathrm{mg} \mathrm{kg}^{-1}$} \\
\hline \multicolumn{7}{|c|}{ Extensive farming system } \\
\hline \multirow{3}{*}{1} & $5.9 *$ & 8.2 & 0.105 & 0.82 & 189 & 187 \\
\hline & $6.0 * *$ & 6.9 & 0.107 & 1.25 & 228 & 174 \\
\hline & $5.8 * * *$ & 6.7 & 0.120 & 1.23 & 203 & 141 \\
\hline \multirow{3}{*}{2} & 6.0 & 8.5 & 0.103 & 0.81 & 201 & 192 \\
\hline & 6.0 & 6.8 & 0.111 & 1.36 & 232 & 150 \\
\hline & 5.7 & 6.6 & 0.127 & 1.35 & 200 & 141 \\
\hline \multirow{3}{*}{3} & 5.9 & 8.2 & 0.101 & 0.79 & 183 & 186 \\
\hline & 6.0 & 7.6 & 0.103 & 1.17 & 256 & 173 \\
\hline & 5.8 & 6.9 & 0.126 & 1.21 & 208 & 171 \\
\hline \multirow{3}{*}{4} & 5.8 & 7.7 & 0.100 & 0.81 & 161 & 199 \\
\hline & 5.9 & 7.2 & 0.107 & 1.32 & 212 & 204 \\
\hline & 5.9 & 6.9 & 0.127 & 1.36 & 208 & 155 \\
\hline \multirow{3}{*}{$\mathrm{LSD}_{05}$} & 0.25 & 1.3 & 0.008 & 0.13 & 48 & 57 \\
\hline & 0.27 & 1.3 & 0.015 & 0.25 & 61 & 37 \\
\hline & 0.62 & 1.7 & 0.020 & 0.18 & 43 & 23 \\
\hline \multirow{3}{*}{$\mathrm{Sx} \%$} & 1.22 & 6.87 & 2.18 & 4.77 & 7.52 & 8.62 \\
\hline & 1.30 & 5.11 & 3.90 & 5.62 & 7.65 & 6.17 \\
\hline & 239 & 5.88 & 7.16 & 4.36 & 6.19 & 4.04 \\
\hline \multicolumn{7}{|c|}{ Organic-sustainable farming system } \\
\hline \multirow{3}{*}{1} & 6.0 & 8.6 & 0.105 & 0.80 & 197 & 181 \\
\hline & 6.1 & 6.9 & 0.107 & 1.26 & 270 & 234 \\
\hline & 5.9 & 7.1 & 0.136 & 1.23 & 222 & 187 \\
\hline \multirow{3}{*}{2} & 5.9 & 8.8 & 0.103 & 0.81 & 176 & 173 \\
\hline & 6.0 & 7.2 & 0.103 & 1.23 & 277 & 233 \\
\hline & 5.8 & 7.0 & 0.142 & 1.28 & 242 & 217 \\
\hline \multirow{3}{*}{3} & 5.9 & 8.1 & 0.104 & 0.82 & 202 & 187 \\
\hline & 5.9 & 7.3 & 0.107 & 1.21 & 266 & 225 \\
\hline & 5.9 & 7.3 & 0.138 & 1.28 & 266 & 234 \\
\hline & 5.8 & 8.5 & 0.102 & 0.81 & 173 & 191 \\
\hline 4 & 6.0 & 6.9 & 0.110 & 1.21 & 239 & 245 \\
\hline & 5.8 & 6.9 & 0.142 & 1.29 & 200 & 224 \\
\hline & 0.42 & 2.0 & 0.016 & 0.13 & 56 & 49 \\
\hline $\mathrm{LSD}_{05}$ & 0.49 & 2.3 & 0.011 & 0.14 & 79 & 40 \\
\hline & 0.11 & 1.4 & 0.021 & 0.12 & 56 & 31 \\
\hline & 2.04 & 6.72 & 4.55 & 4.75 & 8.66 & 7.73 \\
\hline $\mathrm{Sx} \%$ & 2.37 & 6.65 & 2.99 & 3.30 & 8.66 & 4.97 \\
\hline & 0.43 & 4.41 & 3.40 & 3.33 & 6.95 & 4.27 \\
\hline & & Convention & emical far & system & & \\
\hline & 5.9 & 8.2 & 0.105 & 0.84 & 193 & 171 \\
\hline 1 & 5.8 & 6.8 & 0.110 & 1.20 & 284 & 234 \\
\hline & 5.7 & 6.9 & 0.153 & 1.23 & 226 & 186 \\
\hline & 6.0 & 8.5 & 0.103 & 0.84 & 210 & 191 \\
\hline 2 & 5.8 & 6.7 & 0.113 & 1.34 & 274 & 239 \\
\hline & 5.6 & 6.8 & 0.156 & 1.34 & 248 & 206 \\
\hline & 5.9 & 8.2 & 0.099 & 0.80 & 198 & 192 \\
\hline 3 & 5.8 & 6.7 & 0.110 & 1.33 & 271 & 251 \\
\hline & 5.5 & 6.3 & 0.146 & 1.32 & 256 & 223 \\
\hline & 5.8 & 7.7 & 0.099 & 0.84 & 175 & 189 \\
\hline 4 & 5.8 & 6.8 & 0.010 & 1.31 & 243 & 237 \\
\hline & 5.7 & 6.6 & 0.130 & 1.37 & 228 & 220 \\
\hline & 0.39 & 1.9 & 0.013 & 0.12 & 60 & 39 \\
\hline $\mathrm{LSD}_{05}$ & 0.27 & 0.9 & 0.010 & 0.30 & 77 & 30 \\
\hline & 0.81 & 1.7 & 0.015 & 0.24 & 64 & 55 \\
\hline & 2.04 & 6.87 & 3.62 & 4.18 & 8.89 & 6.12 \\
\hline $\mathrm{Sx} \%$ & 1.91 & 3.79 & 2.60 & 6.70 & 8.33 & 3.65 \\
\hline & 3.10 & 5.72 & 2.32 & 5.16 & 7.83 & 7.53 \\
\hline
\end{tabular}

\footnotetext{
* - agrochemical indices before the experiments in 2003, ** - after harvesting in 2007, *** - after harvesting in 2012
} 
During 10 years of the tests soil acidity did not reduce in either extensive or organic-sustainable farming systems. However, in conventional-chemical farming system the soil $\mathrm{pH}$ and exchangeable bases showed clear tendency towards decrease from 6.0 to 5.5 and from 8.2 to 6.3 mequiv $\mathrm{kg}^{-1}$. In this farming system, where physiologically acidic synthetic fertilizers are used, the soil acidification tendency is recorded. The organic $\mathrm{C}$ content variation has the greatest effect on soil properties following that of soil acidity. Long-term tests show that soil organic $\mathrm{C}$ is the result of the balance among the sources and its emission (von Lützow et al., 2006; Johnston et al., 2009). The most important sources of organic $C$ are plant roots, residues and organic fertilizers. Organic matter decomposition in light-textured soils is faster than in heavy soils, which are rich in clay particles.

In the course of our study the ploughing in of the green manure and crop residues affected the accumulation of organic matter in the soil. In the longer term, this organic material mineralizes and enriches the soil with organic C. Within five years (2003-2007) of the crop rotation by $0.38-0.55 \%$ higher and statistically reliable amount of organic $\mathrm{C}$ was determined in all crop rotations and farming systems. Over the next five years (2008-2012) this rate increased slightly more - by $0.04-0.08 \%$. The increase was not substantial, but it is important that even in extensive farming system no signs of soil degradation were observed. It is stated that extensive farming systems preserve $\mathrm{C}$ in soil through reduced soil organic carbon (SOC) decomposition; however, these systems can also have negative effects leading to increased emissions of nitrous oxide $\left(\mathrm{N}_{2} \mathrm{O}\right)$ in humid environments (Baggs et al., 2003; Ball et al., 2008; Rochette, 2008). N,O emissions are much higher than those of carbon dioxide $\left(\mathrm{CO}_{2}\right)$ and must be reduced due to the greenhouse effect. It therefore leads to the implementation of innovative agronomic management, which aims to utilize most $\mathrm{N}$ from plant residues and employ more legumes to supply other plants with N (Florentin et al., 2010; Jensen et al., 2010).

Five-field crop rotations in various farming systems were formed with legumes and cover crops for green manure. The plants were ploughed in and mineralization process turned them into a source of $\mathrm{N}$ for later cultivated plants. After the first 5-year rotation (in 2007), in all crop rotations and farming systems the total $\mathrm{N}$ content of the soil increased from $0.099 \%$ to $0.113 \%$. After the second 5-year period (in 2012) significantly higher content of total $\mathrm{N}$ was determined in conventional-chemical farming system $(0.130-0.163 \%)$ than in organic-sustainable $(0.130-0.153 \%)$ or extensive $(0.120-0.127 \%)$ farming systems. The highest $\mathrm{N}$ content $(0.127-0.156 \%)$ was determined in the soil of the $2^{\text {nd }}$ treatment where lupine and mustard were grown for green manure and rye was undersown with clover. The amount of $\mathrm{P}$ and $\mathrm{K}$, removed with production from the field, is slightly lower than that of N. Phosphorus loss with the yield of cereals is about $30-40 \mathrm{~kg} \mathrm{ha}^{-1}$ and loss of K depends on the plant species (Lazauskas, 2004). The highest amounts of $\mathrm{P}$ were introduced into soil with bone meal in organic-sustainable and with superphosphate in conventional-chemical farming systems and where we established 200-277 and 220-284 mg kg-1 content of P. Phosphorus was not introduced in the soil in extensive farming system, but agrochemical tests show that its content after the 5-year rotation also increased from 161 to $256 \mathrm{mg} \mathrm{kg}^{-1}$. Meanwhile, the soil $\mathrm{K}$ content in this farming system (except for the $4^{\text {th }}$ treatment) decreased by $13-42 \mathrm{mg} \mathrm{kg}^{-1}$.

In the organic-sustainable farming system, the $\mathrm{P}$ content was even higher - 239-277 $\mathrm{mg} \mathrm{kg}^{-1}$, and $\mathrm{K}$ content $-225-245 \mathrm{mg} \mathrm{kg}^{-1}$. In this farming system, $\mathrm{P}$ and $\mathrm{K}$ elements were supplemented by soil fertilization with bone meal and potash magnesia. Comparison of the data obtained after the first crop rotation in 2007 and after the second crop rotation in 2012 showed that the P content in all farming systems and all treatments decreased from 274 to $200 \mathrm{mg} \mathrm{kg}^{-1}$, but it was still higher than the content determined before the experiment. Similar changes were observed in mobile $\mathrm{K}$ contents in organic-sustainable and conventional-chemical farming systems. After the first crop rotation $\mathrm{K}$ content increased from 171 to 251 $\mathrm{mg} \mathrm{kg}{ }^{-1}$, meanwhile after the second crop rotation the $\mathrm{K}$ content decreased from 251 to $186 \mathrm{mg} \mathrm{kg}^{-1}$. In extensive farming system, where $\mathrm{K}$ fertilizers had not been used, the mobile $\mathrm{K}$ content was by $15-51 \mathrm{mg} \mathrm{kg}^{-1}$ lower than 10 years earlier, before the experiment.

Soil physical properties are the basic for productive agriculture. Extreme natural conditions, expanding with climate change, during both wetter and drier periods cause pressure that aggravates any basic condition of soil physical properties (Powlson et al., 2010). Soil physical properties depend on the amount of organic matter in it and on the meteorological conditions. Influence of meteorological conditions is much weaker if the soil is rich in organic matter. The more organic fertilizers (manure, cover crops) are added to the soil, the better it preserves moisture and porosity, and vice versa, the less organic matter in the soil the sooner it loses moisture and the density of the soil increases causing plants to wilt (Dodd et al., 2008; Magdoff, Es, 2009). This is also reflected in our studies. The review of soil physical properties revealed that the soil moisture indices in all farming systems depended on the season (Fig. 1).

Although at the harvest period (autumn) the rainfall amount was significantly lower than in spring (May), after harvesting soil moisture was by $1-2 \%$ higher than in spring. Both in spring and autumn only slight moisture changes were observed regardless of the farming system. However, significantly higher moisture content (1-2\%) was determined in the lower (15-20 $\mathrm{cm})$ soil layer of extensive and conventional-chemical farming systems. Lupine and white mustard grown for green manure in crop rotation in 2003 and 2008 as well as red clover sown after winter rye in 2005 and 2010 produced a significant impact on soil moisture content ( $2^{\text {nd }}$ treatment). It was the result of abundant amount of organic matter added to the soil with green manure and plant residues. In many cases the recorded parameters of soil moisture are statistically significant $\left(\mathrm{LSD}_{05}=\right.$ 0.77-2.08). Soil bulk density was significantly affected by different farming systems (Fig. 2). 

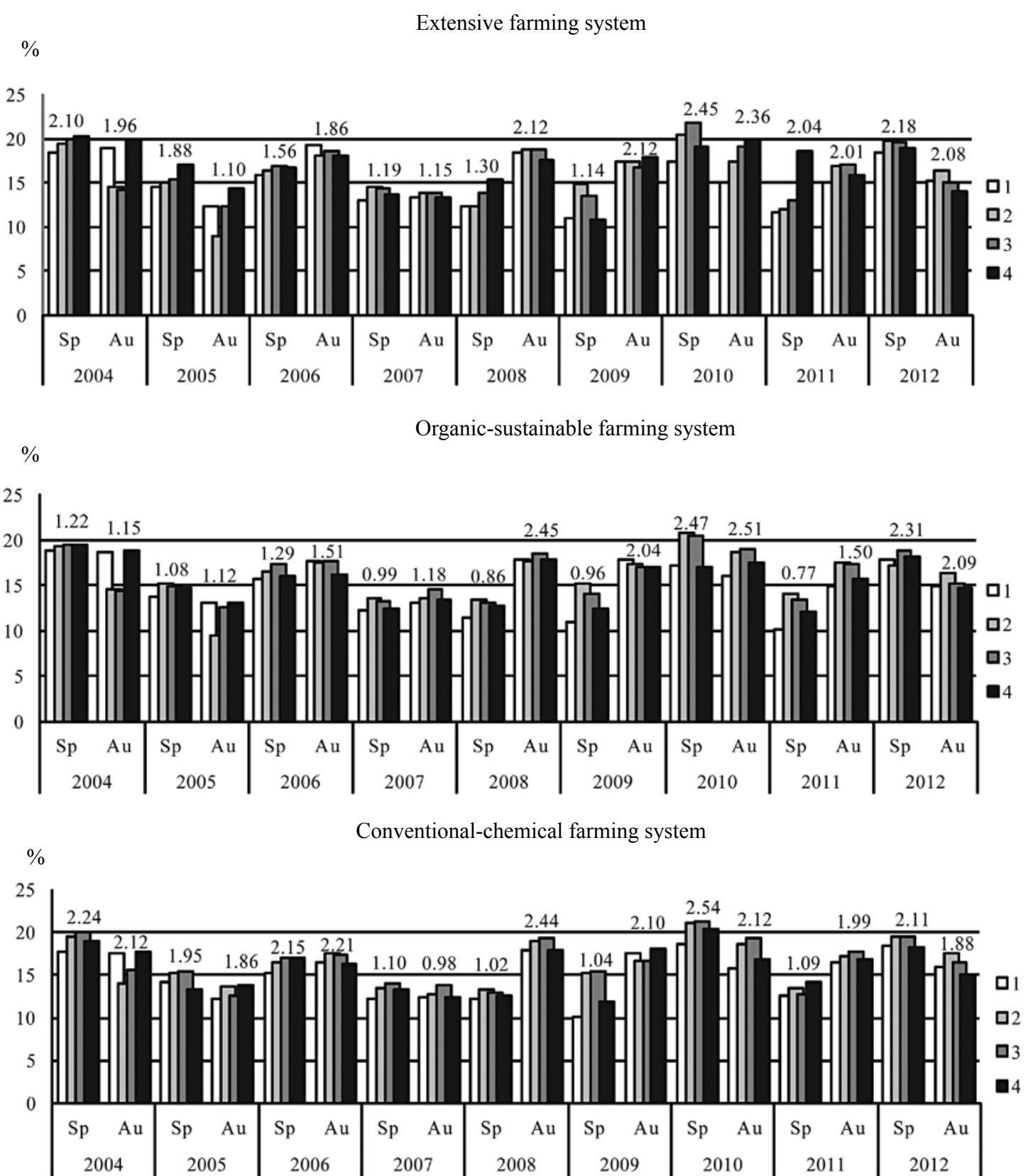

$\mathrm{Sp}$ - spring, after sowing of crop, $\mathrm{Au}$ - autumn, after harvesting; 1-4 - treatments of trials: 1) lupine for green manure, winter rye, potato, buckwheat, barley; 2) lupine for green manure and intermediary white mustard, potatoes, winter rye with undersown red clover, buckwheat, barley; 3) lupine for grain, potatoes, winter rye with intermediary white mustard, buckwheat, barley; 4) peas, winter rye, lupine for grain, buckwheat, barley; $2.24,2.12$ and further on $-\mathrm{LSD}_{05}$.

Figure 1. The effect of farming systems on soil moisture in various crop rotations

In organic-sustainable and conventionalchemical farming systems the density of soil was by 0.12 $0.16 \mathrm{Mg} \mathrm{m}^{-3}$ higher than in extensive farming system. In this system stronger variations of the soil bulk density were observed within seasons and soil layers. It was determined that in autumn the soil bulk density was by $0.06-0.11 \mathrm{Mg} \mathrm{m}^{-3}$ higher. In the extensive farming system, the effect of green manure on soil density reduction was observed. In almost all cases of organic-sustainable and conventional-chemical farming systems the soil bulk density was lower in treatments where lupines and white mustard had been used for green manure. Soil porosity is directly dependent on the soil density. The higher is the soil bulk density, the lower is the porosity and vice versa, the lower is the soil bulk density, the higher is the porosity. This is confirmed by the obtained results. In extensive farming system aeration porosity of soil was lower than in organic-sustainable or conventionalchemical farming systems (Fig. 3).

It was also determined that in all farming systems and treatments of plant sequence the soil aeration porosity was lower in autumn than in spring. Porosity as well as moisture was significantly influenced by the amount of legumes cultivated in the crop rotation. In the 

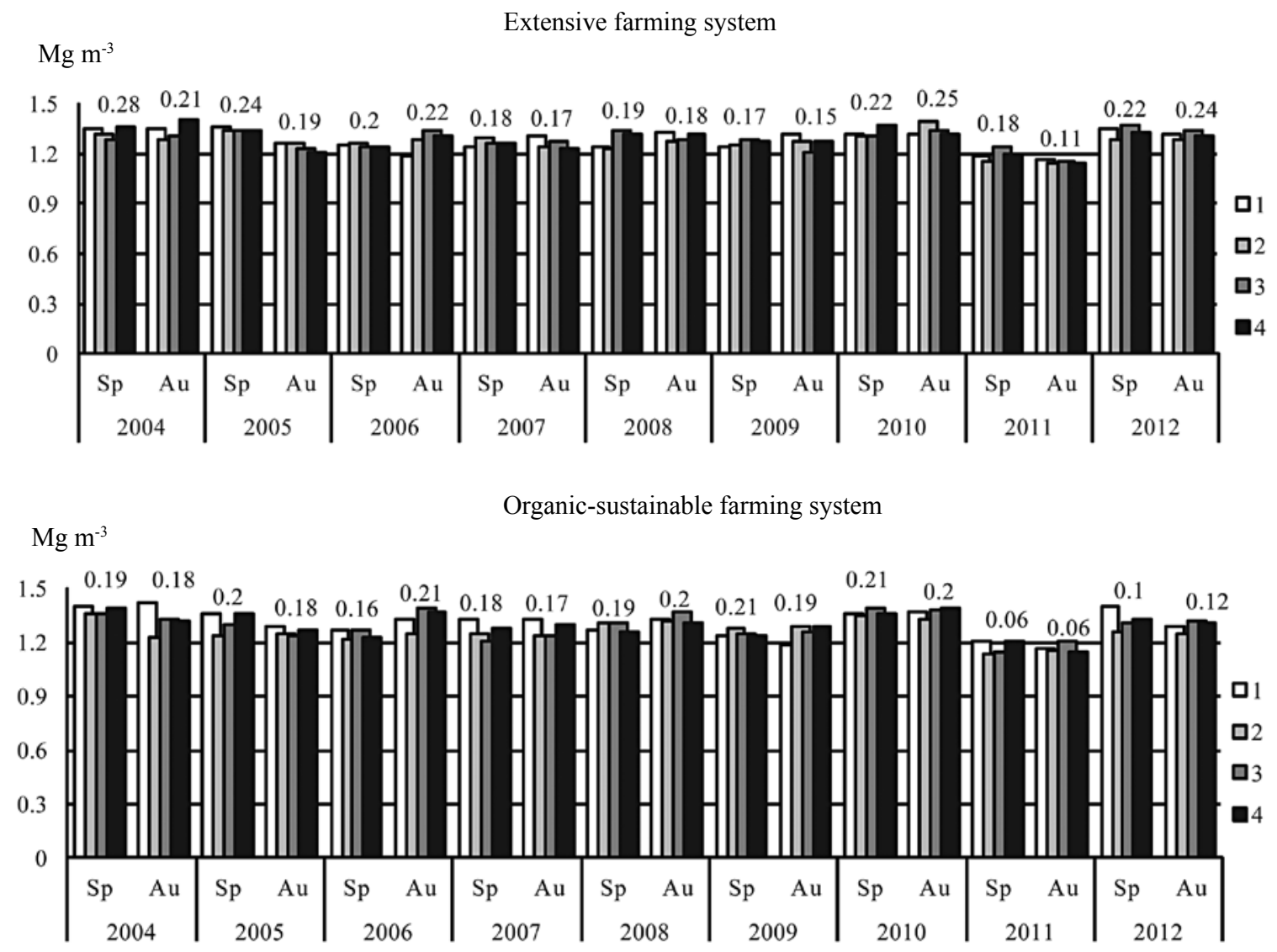

Conventional-chemical farming system

$\mathrm{Mg} \mathrm{m}^{-3}$

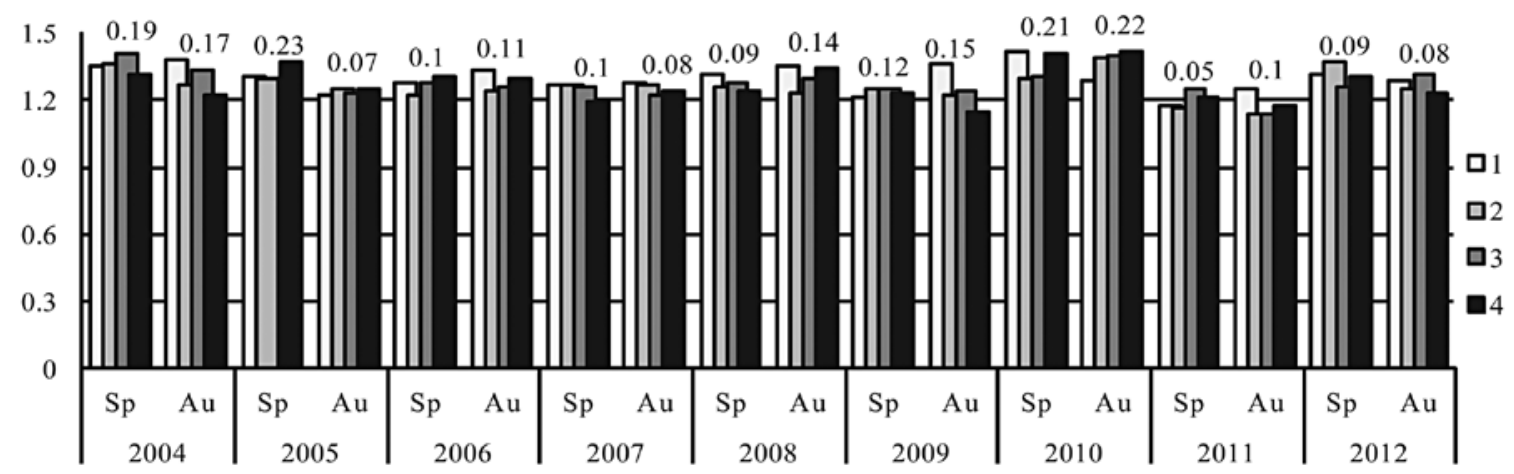

Explanations under Figure 1

Figure 2. The effect of farming systems on soil bulk density in various crop rotations

soil where pre-crop lupines, intermediary white mustard and winter rye with undersown red clover ( $2^{\text {nd }}$ treatment $)$ as well as pea and lupine ( $4^{\text {th }}$ treatment) were grown, the aeration porosity was by $2-4 \%$ higher than in soil of other treatments of plant sequence. The number of various groups of microorganisms is one of the main indicators of biological soil activity and fertility. At the beginning of vegetation and after harvesting the abundance of fungi, ammonifying and mineral $\mathrm{N}$ assimilating bacteria was estimated (Tables 3-5). The analysis of obtained data showed the different influence of applied agricultural systems as well as plants grown in rotation on the number of microorganisms in the soil. The role of fungi able to destroy organic residues to soluble hydrocarbons is very important in plant supply with nutrients (Cesevičius, Janušauskaite, 2006). The number of fungi in the under extensive farming system depended on plants grow (Table 3). The most positive effect on distribution of fungi was estimated when applying third rotation (except first five years in autumn). It was noticed that the number of fungi increased during second five years comparing with the beginning of experiment.

The number of fungi in the soil, where organicsustainable farming system had been applied, persisted stable during the first five years (except, first rotation in autumn). The increase of fungi abundance during 6-10 years of experiment was more marked in the extensive farming system, where the number of fungi became similar 


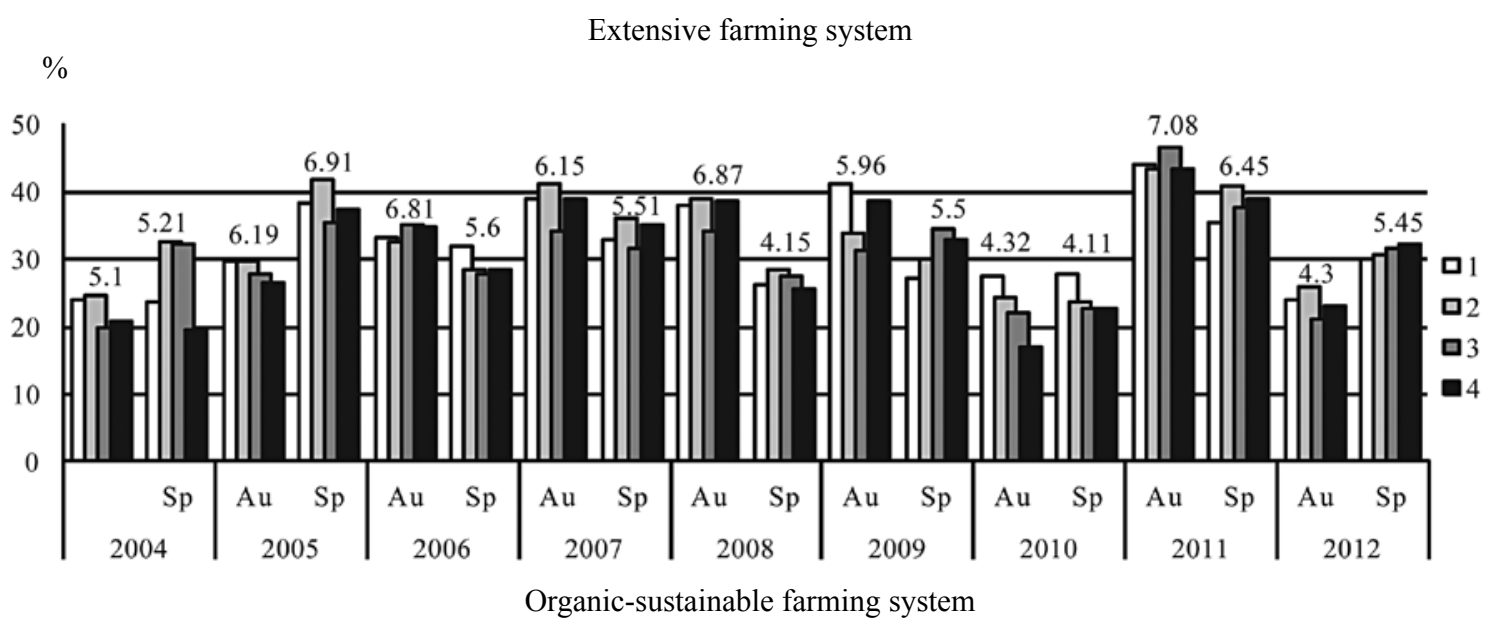

$\%$

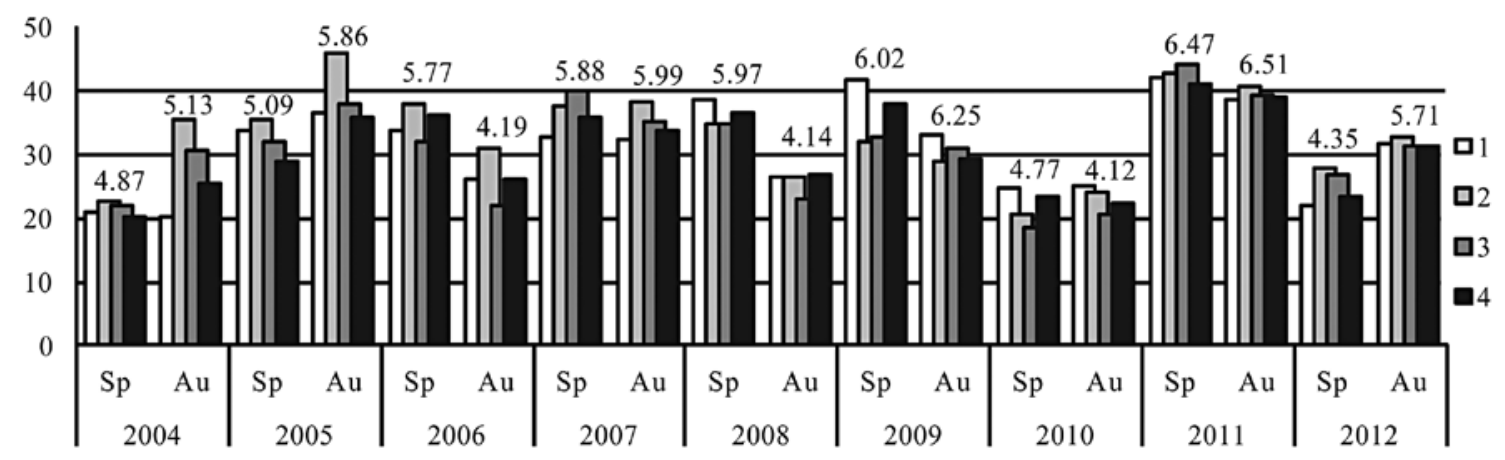

Conventional-chemical farming system

$$
\%
$$

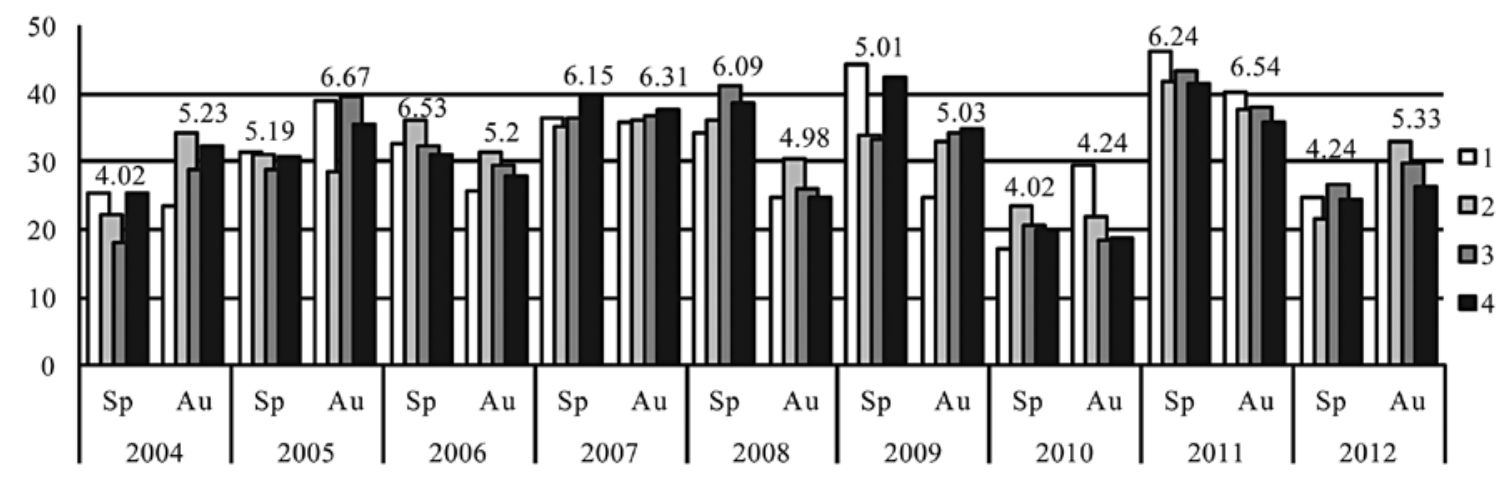

Explanations under Figure 1

Figure 3. The effect of farming systems on soil aeration porosity in various crop rotations

to that in the conventional-chemical farming system. May be due to mineral fertilizers used in this system the major part of fungi belonged to genera Penicillium which are known as producers of toxins (Frisvad et al., 2004). The seasonal differences in abundance of fungi were estimated. When lupine was grown for green manure ( $1^{\text {st }}$ and $2^{\text {nd }}$ treatments), the number of fungi increased in autumn during first five years, though later this effect was not so distinguished. Ammonifying bacteria decompose proteins of plant residues and thus $\mathrm{N}$ compounds become available nutrients for plants (Table 4). These bacteria group was more abundant in autumn then at the beginning of plant vegetation (except for the second rotation in extensive system). The bacteria number averages of the first five and second five years showed that the amount of ammonificators in spring and sometimes in autumn was higher in extensive system compared with organicsustainable and even conventional-chemical systems. The best rotation for the development of ammonifying bacteria was lupine for green manure with mustard, potatoes, winter rye with clover, buckwheat and barley. In autumn rather great number of bacteria were isolated from soil of rotation: lupine, potatoes, winter rye with mustard, buckwheat and barley. The obtained results agreed with the data of other researchers about positive effect of ploughing of green manure together with using moderate rates of mineral fertilizers on ammonifying bacteria in soil (Buciene, 2012). 
Table 3. The effect of farming systems on the amount of fungi in various crop rotations

\begin{tabular}{|c|c|c|c|c|}
\hline \multirow[t]{2}{*}{$\begin{array}{l}\text { Treat- } \\
\text { ment }\end{array}$} & \multicolumn{2}{|c|}{$\begin{array}{l}\text { The average of fungi } \\
\text { number } \\
\left(\mathrm{CFU} \mathrm{g} \mathrm{g}^{-1} \text { d.s. } \times 10^{5}\right) \\
\text { during the first } 5 \text { years } \\
\text { of experiment }\end{array}$} & \multicolumn{2}{|c|}{$\begin{array}{l}\text { The average of fungi number } \\
\left(\mathrm{CFU} \mathrm{g}^{-1} \text { d.s. } \times 10^{5}\right) \\
\text { during the second } 5 \text { years } \\
\text { of experiment }\end{array}$} \\
\hline & $\mathrm{I}$ & II & I & II \\
\hline \multicolumn{5}{|c|}{ Extensive farming system } \\
\hline 1 & 2.7 & 3.1 & 4.0 & 11.2 \\
\hline 2 & 2.7 & 3.0 & 5.4 & 8.4 \\
\hline 3 & 3.3 & 2.9 & 16.2 & 13.7 \\
\hline 4 & 3.2 & 1.9 & 3.5 & 4.6 \\
\hline $\mathrm{LSD}_{05}$ & 0.9 & 0.4 & 1.9 & 1.1 \\
\hline \multicolumn{5}{|c|}{ Organic-sustainable farming system } \\
\hline 1 & 2.6 & 8.8 & 3.1 & 1.8 \\
\hline 2 & 2.6 & 2.6 & 3.3 & 4.4 \\
\hline 3 & 2.5 & 2.1 & 5.7 & 3.8 \\
\hline 4 & 2.7 & 3.0 & 5.0 & 2.9 \\
\hline $\mathrm{LSD}_{05}$ & 0.3 & 0.3 & 0.4 & 0.4 \\
\hline \multicolumn{5}{|c|}{ Conventional-chemical farming system } \\
\hline 1 & 3.1 & 3.3 & 3.0 & 2.1 \\
\hline 2 & 3.3 & 2.8 & 5.2 & 11.9 \\
\hline 3 & 2.9 & 3.4 & 9.2 & 12.6 \\
\hline 4 & 2.9 & 3.6 & 4.3 & 6.7 \\
\hline $\mathrm{LSD}_{05}$ & 0.3 & 0.4 & 0.4 & 0.6 \\
\hline
\end{tabular}

CFU - colony forming units per gram of dry soil; I - at the beginning of vegetation, II - at the end of vegetation

Table 4. The effect of farming systems on the amount of ammonifying bacteria in various crop rotations

\begin{tabular}{|c|c|c|c|c|}
\hline \multirow[t]{2}{*}{$\begin{array}{l}\text { Treat- } \\
\text { ment }\end{array}$} & \multicolumn{2}{|c|}{$\begin{array}{c}\text { The average of } \\
\text { ammonifying bacteria } \\
\text { number } \\
\left(\mathrm{CFU} \mathrm{g}^{-1} \text { d.s. } \times 10^{6}\right) \\
\text { during the first } 5 \text { years } \\
\text { of experiment }\end{array}$} & \multicolumn{2}{|c|}{ 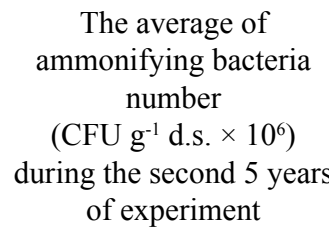 } \\
\hline & I & II & $\mathrm{I}$ & II \\
\hline \multicolumn{5}{|c|}{ Extensive farming system } \\
\hline 1 & 4.9 & 8.4 & 9.7 & 19.8 \\
\hline 2 & 9.2 & 18.1 & 31.8 & 12.5 \\
\hline 3 & 6.8 & 19.0 & 23.3 & 22.2 \\
\hline 4 & 4.6 & 11.6 & 6.9 & 16.6 \\
\hline $\mathrm{LSD}_{05}$ & 1.3 & 1.3 & 2.3 & 1.9 \\
\hline \multicolumn{5}{|c|}{ Organic-sustainable farming system } \\
\hline 1 & 3.2 & 7.5 & 7.7 & 15.5 \\
\hline 2 & 5.6 & 10.6 & 16.1 & 17.3 \\
\hline 3 & 4.0 & 6.7 & 12.6 & 22.8 \\
\hline 4 & 3.9 & 18.6 & 9.8 & 17.0 \\
\hline $\mathrm{LSD}_{05}$ & 0.8 & 1.4 & 1.0 & 1.5 \\
\hline \multicolumn{5}{|c|}{ Conventional-chemical farming system } \\
\hline 1 & 4.5 & 8.6 & 10.5 & 14.1 \\
\hline 2 & 6.2 & 16.7 & 11.5 & 28.7 \\
\hline 3 & 5.6 & 9.6 & 15.7 & 19.9 \\
\hline 4 & 4.1 & 7.2 & 12.4 & 24.9 \\
\hline $\mathrm{LSD}_{05}$ & 0.7 & 1.6 & 1.1 & 2.0 \\
\hline
\end{tabular}

Explanations under Table 3

Mineral $\mathrm{N}$ assimilating bacteria were isolated in significantly more numbers than ammonificators, especially during last five years (Table 5). There are reports that ploughing in of green manure affects distribution of $\mathrm{N}$ assimilating microorganisms positively (Cesevičius, Janušauskaite, 2006; Janušauskaite et al., 2008).
Table 5. The effect of farming systems on the amount of mineral nitrogen $(\mathrm{N})$ assimilating bacteria in various crop rotations

\begin{tabular}{|c|c|c|c|c|}
\hline \multirow[t]{2}{*}{$\begin{array}{l}\text { Treat- } \\
\text { ment }\end{array}$} & \multicolumn{2}{|c|}{ 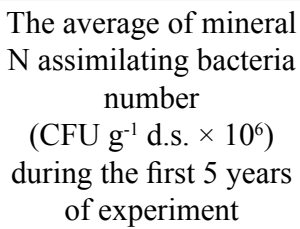 } & \multicolumn{2}{|c|}{$\begin{array}{c}\text { The average of mineral } \\
\mathrm{N} \text { assimilating bacteria } \\
\text { number } \\
\left(\mathrm{CFU} \mathrm{\textrm {g } ^ { - 1 } \mathrm { d } . \mathrm { s } .} \times 10^{6}\right) \\
\text { during the second } 5 \text { years } \\
\text { of experiment }\end{array}$} \\
\hline & I & II & $\mathrm{I}$ & II \\
\hline \multicolumn{5}{|c|}{ Extensive farming system } \\
\hline 1 & 18.1 & 21.3 & 15.4 & 26.8 \\
\hline 2 & 18.1 & 18.8 & 12.5 & 30.1 \\
\hline 3 & 19.0 & 20.4 & 22.2 & 31.1 \\
\hline 4 & 16.6 & 20.0 & 23.4 & 37.7 \\
\hline $\mathrm{LSD}_{05}$ & 2.8 & 2.4 & 2.2 & 2.8 \\
\hline \multicolumn{5}{|c|}{ Organic-sustainable farming system } \\
\hline 1 & 16.8 & 18.8 & 14.4 & 23.2 \\
\hline 2 & 16.5 & 20.3 & 25.2 & 22.5 \\
\hline 3 & 17.3 & 22.0 & 24.8 & 24.0 \\
\hline 4 & 16.0 & 19.8 & 16.7 & 20.9 \\
\hline $\mathrm{LSD}_{05}$ & 2.9 & 1.9 & 2.3 & 2.0 \\
\hline \multicolumn{5}{|c|}{ Conventional-chemical farming system } \\
\hline 1 & 14.1 & 18.1 & 19.0 & 19.8 \\
\hline 2 & 13.1 & 17.6 & 17.6 & 31.9 \\
\hline 3 & 17.2 & 16.4 & 13.8 & 33.1 \\
\hline 4 & 15.4 & 20.0 & 23.5 & 29.4 \\
\hline $\mathrm{LSD}_{05}$ & 3.3 & 32 & 2.2 & 3.3 \\
\hline
\end{tabular}

Explanations under Table 3

During the experiment in $62.5 \%$ cases of extensive and organic-sustainable systems the number of this bacteria group was higher than in conventionalchemical system. The ratio of ammonifying to mineral $\mathrm{N}$ immobilizing microorganisms shows trends of mineralization-humification process and ecological state of soil (Piaulokaitè-Motuzienè et al., 2004). It has been reported that after fertilizing with organic fertilizers the part of mineral $\mathrm{N}$ assimilating microorganisms increased to $85 \%$ (Arlauskiene, 1999). In our experiment the part of ammonifying and mineral $\mathrm{N}$ assimilating bacteria (mineralization-immobilization coefficient) was calculated. The obtained data show that the part of mineral $\mathrm{N}$ assimilating bacteria prevailed in $83.3-90 \%$ of the studied soil samples. In organic-sustainable and conventional-chemical systems, rather frequently the prevalence of ammonificators was found under monocultures of buckwheat and barley (in 2011 and 2012). Application of extensive system decreased negative effect of monocultures on the balance of mineralization and humification processes.

In summary, we can predict that the applied short crop rotations where plant sequence was applied aiming to ensure maximum organic matter and $\mathrm{N}$ accumulation in the soil, the extensive farming system as well as organic-sustainable does not impoverish the light-textured soils.

\section{Conclusions}

1. The analysis of agrochemical parameters of sandy loam Haplic Luvisol ( $L V h$ ) revealed that various crop rotation treatments used in extensive, organicsustainable and conventional-chemical farming systems had no significant effect on the soil acidity. In all cases, 
the parameters of soil $\mathrm{pH}$ and exchangeable bases varied within the error range. In all farming systems and all crop rotation treatments, the contents of total nitrogen $(0.002-0.011 \%)$ and organic carbon $(0.36-0.55 \%)$ increased. These contents were higher in the crop rotation treatments where lupine and cruciferous plants for green manure, and winter rye with undersown red clover had been grown. After the first crop rotation the phosphorus content increased by $31-101 \mathrm{mg} \mathrm{kg}^{-1}$, but after the second crop rotation it decreased by $15-58 \mathrm{mg} \mathrm{kg}^{-1}$. Increase of potassium content by $38-63 \mathrm{mg} \mathrm{kg}^{-1}$ was observed only in organic-sustainable and conventional-chemical farming systems.

2. The different farming systems and crops rotations had the respective influence on the soil moisture, soil bulk density and aeration porosity. In the soils under extensive and conventional-chemical farming systems moisture content significantly increased by $1-2 \%$. The soil bulk density in autumn was by $0.06-0.11 \mathrm{Mg} \mathrm{m}^{-3}$ higher than in spring. In the extensive farming system the influence of green manure on the reduction of soil bulk density became evident. Abundance of legumes cultivated in the crop rotation had greater influence on the aeration porosity. In the soil where pre-crop lupines, intermediary white mustard and winter rye with undersown red clover ( $2^{\text {nd }}$ treatment $)$ as well as pea and lupine ( $4^{\text {th }}$ treatment $)$ were grown, the aeration porosity was by $2-4 \%$ higher than in the soil under other variants of plant sequence.

3 . The extensive farming system was more suitable for the distribution of fungi in the soil compared with organic-sustainable system. During the second five years of experiment the amount of fungi in the extensive farming system became comparable to the number of fungi isolated from soil where chemical system had been applied. The considerable increase of fungi during the second five years of experiment was estimated. Plants growing as green manure positively affected the abundance of ammonifying bacteria. The greatest number of mineral $\mathrm{N}$ assimilating bacteria was estimated at the end of vegetation, when the degradation of plant residues by fungi and ammonificators occurred. The application of organic farming system maintained the balance between mineralization and humification processes in the soil.

\section{Acknowledgements}

The study was conducted while implementing the long term program "Plant biopotential and quality for multifunctional practice".

Received 05072013

Accepted 25022014

\section{References}

Arlauskiene E. A. 1999. Changes of microbial cenosis under systematic manuring. Ekologija, 3: 43-46 (in Lithuanian)

Baggs E. M., Stevenson M., Pihlatie M., Regar A., Cook H., Cadisch G. 2003. Nitrous oxide emissions following application of residues and fertiliser under zero and conventional tillage. Plant and Soil, 254: 361-370 http://dx.doi.org/10.1023/A:1025593121839

Ball B. C., Crichton I., Horgan G. W. 2008. Dynamics of upward and downward $\mathrm{N}_{2} \mathrm{O}$ and $\mathrm{CO}_{2}$ fluxes in ploughed or no-tilled soils in relation to water-filled pore space, compaction and crop presence. Soil and Tillage Research, 101: 20-30 http://dx.doi.org/10.1016/j.still.2008.05.012
Buciene A. 2012. On the sustainability of conventional, organic and integrated farming systems. Sustainable Agriculture, p. 42-50. <http://www.diva-portal.org/smash/record jsf?pid=diva2:601877> [accessed 0507 2013]

Cesevičius G., Janušauskaite D. 2006. Soil microbological and physical properties in various tillage systems. ZemdirbysteAgriculture, 93 (3): 18-34

Dodd I. C., Egea G., Davies W. J. 2008. Accounting for sap flow from different parts of the root system improves the prediction of xylem ABA concentration in plants grown with heterogeneous soil moisture. Journal of Experimental Botany, 59: 4083-4093 http://dx.doi.org/10.1093/jxb/ern246

Florentin M. A., Penalva M., Calegari A., Derpsch R. 2010. Green manure/cover crops and crop rotation in conservation agriculture on small farms. Integrated Crop Management, vol. $12,97 \mathrm{p}$.

Frisvad J. C., Smedsgaard J., Larsen T. O., Samson R. A. 2004. Mycotoxins, drugs and other extrolites produced by species in Penicillium subgenus Penicillium. Studies in Mycology, 49: 201-241

GOST 26208-91: 1993. Soils. Determination of mobile compounds of phosphorus and potassium by Egner-RiemDomingo method (AL-method). Moscow, Russia

IFOAM 2008. Definition of organic agriculture. $<\mathrm{http} / / \mathrm{www}$. ifoam.org/en/organic-landmarks/definition-organicagriculture $>$ [accessed 0507 2013]

ISO 10390: 1994. Soil quality. Determination of $\mathrm{pH}$. TC 190/ SC 3

ISO 11260: 1994. Soil quality. Determination of effective cation exchange capacity and base saturation level using barium chloride solution. TC 190/SC 3

ISO 11261: 1995. Soil quality. Determination of total nitrogen - Modified Kjeldahl method. TC 190/SC 3

ISO 14235: 1998. Soil quality. Determination of organic carbon by sulfochromic oxidation. TC 190/SC 3

Jakobsen M. 2012. Introducing farmer group learning and development into organic small holder farming systems in the global south - including a case study from the state of Madhya Pradesh, India. Organic Farming in a Development Perspective. Aarhus University, Denmark, 15 p.

Jaskulski D., Jaskulska I. 2012. Plant diversity in agroecosystems and agricultural landscapes. Gbolagade A. L. (ed.). Biodiversity conservation and utilization in a diverse world, Chapter 1

Janušauskaite D., Velykis A., Satkus A. 2008. The influence of agriculture practices intended for the improvment of clay loam topsoil and subsoil on the microbiological processes. Zemdirbyste-Agriculture, 95 (2): 45-60

Jensen E. S., Peoples M. B., Hauggaard-Nielsen H. 2010. Faba bean in cropping systems. Field Crops Research, 115: 203-216 http://dx.doi.org/10.1016/j.fcr.2009.10.008

Johnston A. E., Poulton P. R., Coleman K. 2009. Soil organic matter: its importance in sustainable agriculture and carbon dioxide fluxes. Advances in Agronomy, 101: 1-57 http://dx.doi.org/10.1016/S0065-2113(08)00801-8

Kibblewhite M. G, Ritz K., Swift M. J. 2008. Soil health in agricultural systems. Philosophical transactions of the Royal society. Biological Sciences, 363 (1492): 685-701 http://dx.doi.org/10.1098/rstb.2007.2178

Lazauskas P. 2004. Organic crop production and horticulture. Plant Nutrition Balance in Organic Farming. <http:/www. asu.lt/tracoecobalt/files/outgrowth/books/lzuu en/about project.htm> [accessed 0507 2013]

LST ISO 10381-6: 1998. Soil quality. Sampling. Part 6. Guidance on the collection, handling and storage of soil under aerobic conditions for the assessment of microbiological processes, biomass and diversity in the laboratory

Magdoff F., Es H. 2009. Building soils for better crops: sustainable soil management. Sustainable Agriculture Research and Education (SARE) program, 294 p. 
McCauley A., Jones C., Jacobsen J. 2009. Soil pH and organic matter. Nutrient Management Module, No. 8, 12 p.

Piaulokaitè-Motuzienė L., Lapinskas E., Čiuberkienè D. 2004. The effects of soil acidity and mineral fertilizers on the occurance of ammonifying and minaral nitrogen assimilating microorganisms in the soil. ZemdirbysteAgriculture, 88 (4): 198-205

Powlson D. S., Whitmore A. P., Goulding K. W. T. 2010. Soil carbon sequestration for mitigating climate change: distinguishing the genuine from the imaginary. Hillel D., Rosenweig C. (eds). Handbook of climate change and agroecosystems, ICP Series on Climate Change Impacts, 1: 393-402

Rachman A., Anderson S. H., Gantzer C. J. Thompson A. L. 2003. Influence of long-term cropping systems on soil physical properties related to soil erodibility. Soil Science Society of America Journal, 67: 637-644 http://dx.doi.org/10.2136/sssaj2003.6370

Rochette R. 2008. No-till only increases $\mathrm{N}_{2} \mathrm{O}$ emissions in poorly-aerated soils. Soil and Tillage Research. 101: 97100 http://dx.doi.org/10.1016/j.still.2008.07.011

Soil sampling and methods of analysis. 1993. Carter M. R. (ed.). London, Tokyo, $823 \mathrm{p}$.
Tarakanovas P., Raudonius S. 2003. Agronomimniu tyrimu duomenų statistiné analizè taikant kompiuterines programas ANOVA, STAT, SPLIT-PLOT iš paketo SELEKCIJA ir IRRISTAT. Lithuanian University of Agriculture, $58 \mathrm{p}$. (in Lithuanian)

Tripolskaja L. 2005. Organic fertilisers and their effect on the environment. Lithuanian Institute of Agriculture, $216 \mathrm{p}$. (in Lithuanian)

von Lützow M., Kögel-Knabner I., Ekschmitt K., Matzner E., Guggenberger G., Marschner B., Flessa H. 2006. Stabilization of organic matter in temperate soils: mechanisms and their relevance under different soil conditions - a review. European Journal of Soil Science, 57: 426-445 http://dx.doi.org/10.1111/j.1365-2389.2006.00809.x

Wander M. 2009. Agroecosystem integrity and the internal cycling of nutrients. Bohlen P., House G. (eds). Sustainable agroecosystem management: integrating ecology, economics, and society, p. 137-166

Wang L. K., Ivanov V., Tay J. H. 2010. Environmental biotechnology. Handbook of Environmental Engineering, 10: $397 \mathrm{p}$.

ISSN 1392-3196 / e-ISSN 2335-8947

Zemdirbyste-Agriculture, vol. 101, No. 2 (2014), p. 115-124

DOI $10.13080 /$ z-a.2014.101.015

\title{
Ivairių žemdirbystès sistemų įtaka Pietryčių Lietuvos mažo našumo dirvožemio tvarumui
}

\author{
E. Bakšienè ${ }^{1}$, A. Ražukas ${ }^{1}$, J. Repečkiené2 ${ }^{2}$ J. Titova ${ }^{1}$ \\ ${ }^{1}$ Lietuvos agrarinių ir miškų mokslų centro Vokès filialas \\ ${ }^{2}$ Gamtos tyrimų centro Botanikos institutas
}

\section{Santrauka}

Lietuvos agrarinių ir miškų mokslų centro Vokès filiale 2003-2012 m. atlikti kompleksiniai tyrimai, kurių tikslas - ištirti ekstensyviosios, ekologinès-tausojamosios ir intensyviosios-cheminès žemdirbystės sistemų dirvožemio cheminių, fizikinių bei mikrobiologinių savybių pokyčiams priesmèlio paprastajame išplautžemyje (IDp). Tyrimai atlikti skirtingų sejjomainų rotacijose, kuriose augalų kaita išdèstyta 4 variantais, kad jų liekanos dirvožemyje sukauptų kuo daugiau organinès medžiagos ir azoto. Tyrimų duomenys parodè, kad įvairios žemdirbystės sistemos ir augalų išdèstymas sėjomainose neturèjo įtakos dirvožemio rūgštumui, tačiau gerokai padidino suminio azoto bei organinès anglies ir sumažino judriujų fosforo bei kalio kiekius. Taip pat atitinkamai kito ir dirvožemio fizikinès savybès. Drègmės daugiau nustatyta dirvožemyje, kuriame taikyta ekstensyvioji ir intensyvioji-cheminè žemdirbystès sistemos. Dirvožemių gilesniuose sluoksniuose išryškèjo žaliosios trąšos įtaka dirvožemio tankio sumažèjimui ir bendrojo bei aeracinio poringumo padidejjimui. Ekstensyvioji ir ekologinètausojamoji žemdirbystès sistemos teigiamai veikè mikromicetų pasiskirstymą dirvožemyje. Daugiausia grybų nustatyta tausojamają žemdirbystės sistemą taikant po lubinų ir baltųjų garstyčių priešsèlio, auginto žaliajai trąšai. Taikant ekstensyviają žemdirbystès sistemą tarp amonifikuojančių ir mineralinį azotą asimiliuojančių bakterijų nusistovejo pusiausvyra.

Reikšminiai žodžiai: bakterijos, cheminès ir fizikinès savybės, dirvožemis, mikromicetai, žemdirbystès sistemos. 